\title{
Studi Interaksi Senyawa Turunan Saponin dari Daun Bidara Arab (Ziziphus spina-christi L.) sebagai Antiseptik Alami secara In Silico
}

(Interaction study of saponin derivative compounds from arabic bidara leaves (Ziziphus spina-christi L.) as natural antiseptic through in silico)

\author{
Fitrianti Darusman*, Taufik Muhammad Fakih \\ Program Studi Farmasi, Fakultas Matematika dan IImu Pengetahuan Alam, Universitas Islam Bandung, Jl. Rangga \\ Gading No.8, Tamansari, Kec. Bandung Wetan, Kota Bandung, Jawa Barat
}

\begin{abstract}
Christinin is a saponin glycoside derivative which is the most abundant in the leaves of Arabic bidara (Ziziphus spinachristi L.). This compound is thought to have activity as an effective antimicrobial against bacteria and fungi, such as Staphylococcus epidermidis, Escherichia coli, and Candida albicans which often cause infections on the skin surface which can usually be treated with use of an antiseptic solution. This study aims to identify, evaluate and explore the affinity and molecular interactions between christinin-A, B, C, and D against target macromolecules in Staphylococcus epidermidis, Escherichia coli and Candida albicans by using in silico molecular docking simulations. The geometry of the test compound molecule was optimized first by using GaussView 5.0.8 and Gaussian09 software. The best conformation was chosen for interaction studies on target macromolecules using MGLTools 1.5.6 software equipped with AutoDock 4.2. The interactions that were formed were then observed using the BIOVIA Discovery Studio 2020 software. Based on the results of molecular docking simulations, christinin compounds have good affinity for target macromolecules in Staphylococcus epidermidis, Escherichia coli and Candida albicans. Thus, it is predicted that this compound can be used as a candidate for the main component of natural antiseptics.
\end{abstract}

Keywords: sidr leaf; christinin; natural antiseptic; molecular docking simulation; in silico study.

ABSTRAK: Christinin merupakan senyawa turunan glikosida saponin yang paling banyak terdapat dalam daun bidara arab (Ziziphus spina-christi L.). Senyawa ini diduga memiliki aktivitas sebagai antimikroba yang efektif terhadap bakteri dan jamur, seperti Staphylococcus epidermidis, Escherichia coli, dan Candida albicans yang sering menyebabkan infeksi pada permukaan kulit yang biasanya dapat diatasi dengan penggunaan cairan antiseptik. Penelitian ini bertujuan untuk mengidentifikasi, mengevaluasi serta mengeksplorasi afinitas dan interaksi molekular antara senyawa christinin-A, B, C, dan D terhadap makromolekul target pada Staphylococcus epidermidis, Escherichia coli dan Candida albicans dengan menggunakan simulasi penambatan molekular secara in silico. Molekul senyawa uji terlebih dahulu dioptimasi geometri dengan menggunakan perangkat lunak GaussView 5.0.8 dan Gaussian09. Konformasi terbaik dipilih untuk dilakukan studi interaksi terhadap makromolekul target dengan menggunakan perangkat lunak MGLTools 1.5.6 yang dilengkapi dengan AutoDock 4.2. Interaksi yang terbentuk selanjutnya diamati dengan menggunakan perangkat lunak BIOVIA Discovery Studio 2020. Berdasarkan hasil dari simulasi penambatan molekular, senyawa christinin memiliki afinitas yang baik terhadap makromolekul target pada Staphylococcus epidermidis, Escherichia coli dan Candida albicans. Dengan demikian, senyawa tersebut diprediksi dapat digunakan sebagai kandidat komponen utama dari antiseptik alami.

Kata kunci: daun bidara arab; christinin; antiseptik alami; aimulasi penambatan molekular; studi in silico.

\section{Pendahuluan}

Bidara arab atau Ziziphus sphina-christi (L.), Willd. (Rhamnaceae) merupakan tanaman yang memiliki potensi dalam industri obat tradisional. Bagian daun dari tanaman ini diketahui memiliki aktivitas antimikroba yang efektif terhadap beberapa bakteri seperti Escherichia coli, Staphylococcus epidermidis, Pseudomonas aeruginosa, Salmonella typimurum, Proteus merabilis, Klebsiella pneumonia, Enterobacter spp., Acinetobacter, Serratia spp., Staphylococcus aureus, Staphylococcus saprophytycus, Streptococcus pyogenes, dan
Streptococcus pneumoniae [1-3].

Di samping itu, tanaman ini juga memiliki aktivitas antijamur terhadap Candida albicans, Trichophyton rubrum, Trichophyton mentagaphytes, Microsporum canis, dan Aspergillus fumigatus [4,5]. Senyawa metabolit sekunder dalam ekstrak daun bidara yang dapat menghambat pertumbuhan mikroba yaitu alkaloid, flavonoid, polifenol, tanin dan saponin [6]. Telah diketahui sebelumnya bahwa ekstrak butanol daun bidara arab yang diisolasi terdapat empat

*Corresponding Author: Fitrianti Darusman Program Studi Farmasi, Fakultas Matematika dan IImu Pengetahuan Alam, Universitas Islam Bandung, Jl. Rangga Gading No.8, Tamansari, Kota Bandung, Jawa Barat, 40116 | Email: efit.bien@gmail.com

\section{Article history}

Received: 19 Sept 2020 Accepted: 09 Nov 2020 Published: 30 Des 2020

Access this article

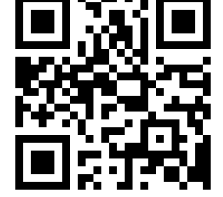


glikosida saponin triterpenoidal yang diberi nama masingmasing christinin-A, B, C dan D. Christinin-A merupakan saponin utama dengan struktur inti steroida $[7,8]$.

Dalam upaya pengembangan antiseptik alami dari daun bidara arab, maka dilakukan uji aktivitas antara beberapa senyawa turunan glikosida saponin triterpenoidal, yaitu christinin-A, B, C, dan D terhadap reseptor target pada beberapa bakteri yang meliputi Penicillin-Binding Protein 3 (PBP3) dari Escherichia coli [9], Filamentous TemperatureSensitive Mutant Z (FtsZ) dari Staphylococcus epidermidis [10], dan N-myristoyl Transferase dari Candida albicans [11]. Penelitian ini dilakukan dengan memanfaatkan studi in silico yang bertujuan untuk mengidentifikasi, mengevaluasi, dan mengekplorasi interaksi molekular yang terbentuk sehingga diharapkan didapat senyawa turunan glikosida saponin triterpenoidal yang paling berpotensi sebagai antiseptik alami.

\section{Metode Penelitian}

\section{Preparasi Senyawa Uji}

Senyawa uji yang akan digunakan dalam penelitian ini adalah senyawa turunan glikosida saponin triterpenoidal, yaitu christinin-A, B, C, dan D (Gambar 1) [7,8]. Struktur molekul senyawa uji dilakukan optimasi geometri terlebih dahulu dengan menggunakan perangkat lunak GaussView
5.0.8 dan Gaussian09 [12]. Metode yang dipilih pada tahap optimasi geometri ini adalah metode semi empiris dengan basis set AM1. Struktur molekul senyawa uji yang telah dioptimasi dan dimodifikasi data muatan parsialnya digunakan sebagai input untuk simulasi penambatan molekular.

\section{Preparasi Makromolekul Target}

Makromolekul target yang digunakan dalam penelitian ini merupakan reseptor pada beberapa bakteri yang meliputi Penicillin-Binding Protein 3 (PBP3) dari Escherichia coli [9], Filamentous Temperature-Sensitive Mutant Z (FtsZ) dari Staphylococcus epidermidis [10], dan N-myristoyl Transferase dari Candida albicans [11]. Makromolekul target tersebut diperoleh dari web Protein Data Bank (http://www.rcsb.org/pdb) dengan kode PDB masing-masing 4EBN dengan resolusi 2,85 $\AA$ [13], 4M8I dengan resolusi $1,43 \AA$ [14], dan 1 IYK dengan resolusi 2,30 A [15] (Gambar 2). Struktur kristal makromolekul target yang telah diunduh dari web Protein Data Bank kemudian dipreparasi dengan menggunakan perangkat lunak MGLTools 1.5.6 yang dilengkapi dengan AutoDock 4.2. Tahap preparasi makromolekul target ini dilakukan dengan menghilangkan molekul air dan ligan alami serta menambahkan atom hidrogen polar dan menghitung muatan parsial Kollman [16,17].

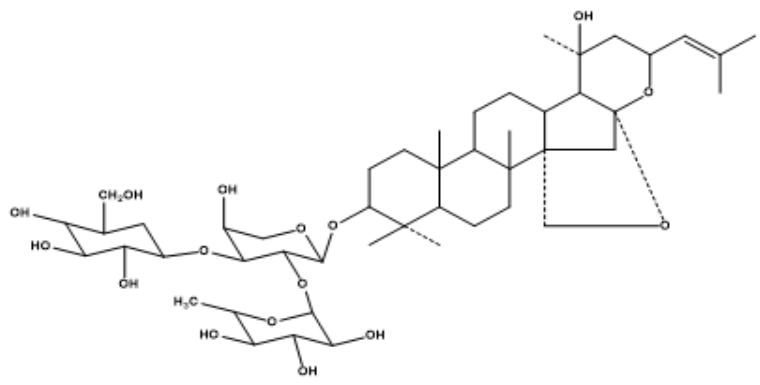

Christinin-A

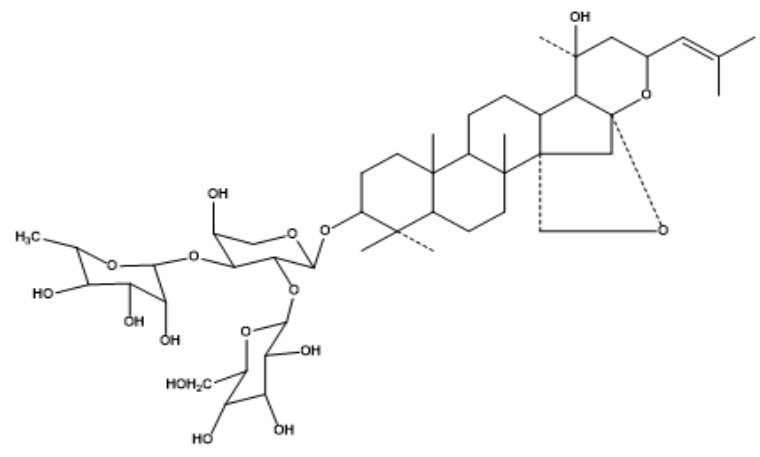

Christinin-C

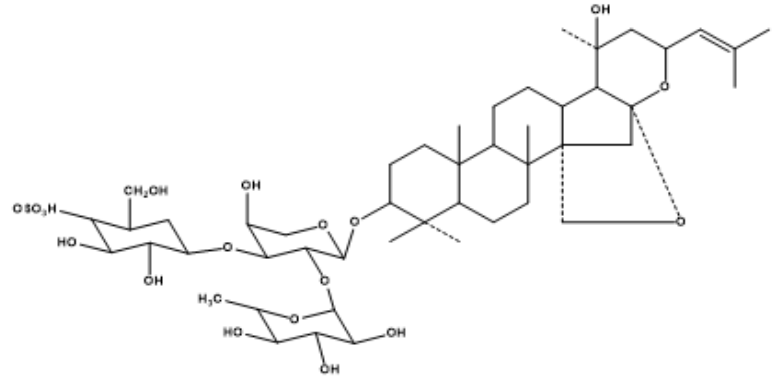

Christinin-B

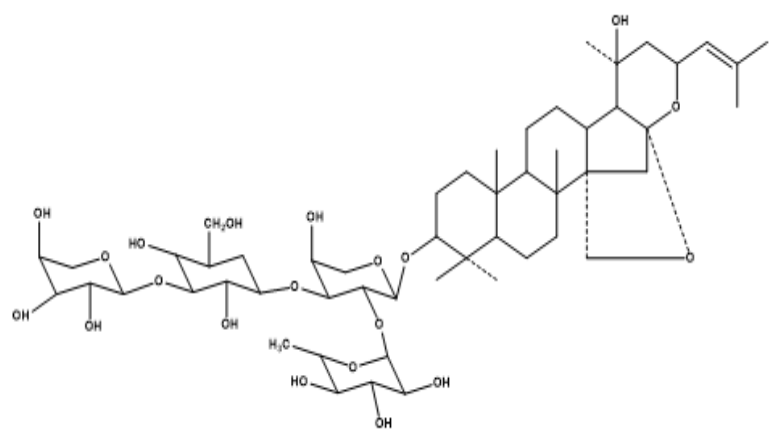

Christinin-D

Gambar 1. Struktur molekul senyawa christinin 


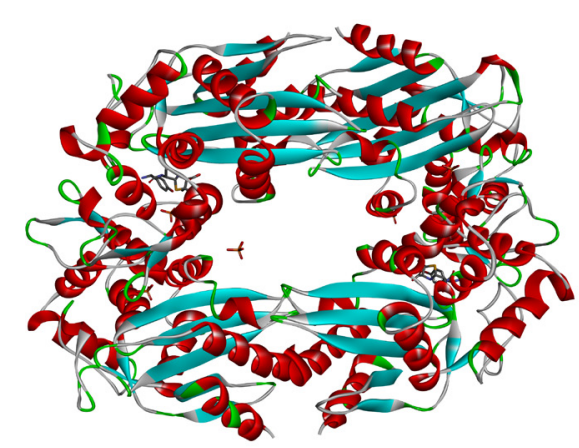

Penicillin-Binding Protein 3 (PBP3) dari Escherichia coli

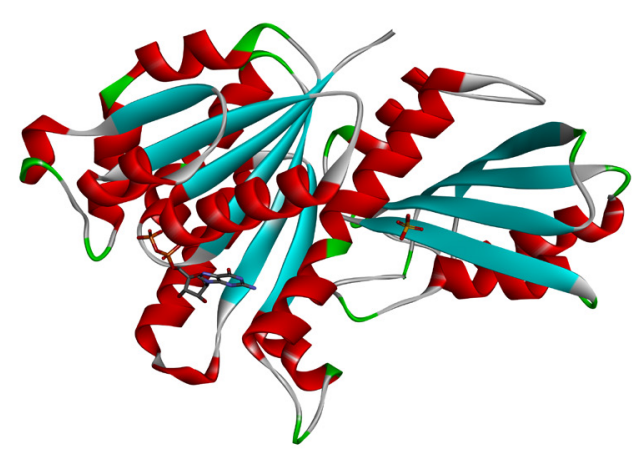

Filamentous Temperature-Sensitive Mutant Z (FtsZ) dari Staphylococcus epidermidis

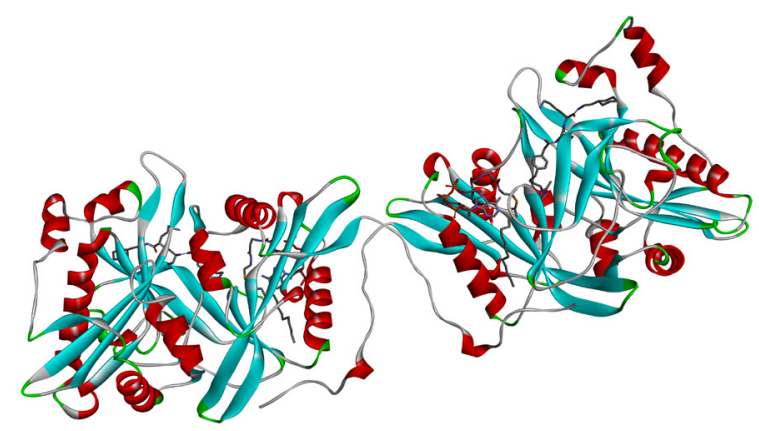

N-myristoyl Transferase dari Candida albicans

Gambar 2. Struktur kristal makromolekul reseptor target

\section{Validasi Metode Penambatan Molekular}

Sebelum dilakukan simulasi penambatan molekular antara molekul senyawa uji dan makromolekul target, terlebih dahulu harus dilakukan validasi metode dengan menggunakan perangkat lunak MGLTools 1.5.6 yang dilengkapi dengan AutoDock 4.2 untuk menentukan beberapa parameter yang akan digunakan pada simulasi penambatan molekular. Validasi metode terhadap parameter penambatan molekular dilakukan dengan menggunakan metode re-docking. Pada proses re-docking ini nilai Root Mean Square Deviation (RMSD) dibatasi dengan radius maksimum $2 \AA[18-20]$.

\section{Simulasi Penambatan Molekular}

Simulasi penambatan molekular dilakukan dengan menggunakan perangkat lunak MGLTools 1.5.6 yang dilengkapi dengan AutoDock 4.2 untuk mengamati dan mengidentifikasi afinitas dan interaksi molekular yang terbentuk antara makromolekul target dengan molekul senyawa uji. Jarak antara bagian permukaan makromolekul target dan molekul senyawa uji dibatasi dengan batas radius maksimum $0,375 \AA$. Semua simulasi dilakukan menggunakan ukuran grid box 94 x 90 x 90 dan metode Lamarckian Genetic Algorithm dengan 100 konformasi $[21,22]$.

Identifikasi Hasil Simulasi Penambatan Molekular

Hasil yang diperoleh dari simulasi penambatan molekular kemudian diidentifikasi, dievaluasi, dan dieksplorasi interaksi molekular yang terbentuk antara

Tabel 1. Nilai energi total molekul senyawa uji hasil optimasi geometri

\begin{tabular}{cc}
\hline Senyawa Uji & Energi Total \\
\hline Christinin-A & $-1,21023344$ \\
Christinin-B & $-1,42436566$ \\
Christinin-C & $-1,28240292$ \\
Christinin-D & $-1,52824472$ \\
\hline
\end{tabular}


Tabel 2. Nilai RMSD hasil validasi metode penambatan molekular

\begin{tabular}{|c|c|c|}
\hline Makromolekul Reseptor & RMSD & Residu Asam Amino \\
\hline $\begin{array}{l}\text { Penicillin-Binding Protein } 3 \text { (PBP3) dari Escherichia } \\
\text { coli }\end{array}$ & $1,87 \AA$ & Ser307, Ser359, Asn361, Tyr419, Lys494, Thr497, Lys499, Tyr511, Tyr541 \\
\hline $\begin{array}{l}\text { Filamentous Temperature-Sensitive Mutant Z (FtsZ) } \\
\text { dari Staphylococcus epidermidis }\end{array}$ & $1,60 \AA$ & Gly21, Gly22, Arg29, Met105, Gly108, Thr109, Gly110, Thr133, Asn166, Phe183 \\
\hline N-myristoyl Transferase dari Candida albicans & $1,73 \AA$ & Tyr107, Val108, Phe117, His227, Phe240, Asp412 \\
\hline
\end{tabular}

makromolekul target dengan molekul senyawa uji berdasarkan nilai energi bebas ikatan [23,24]. Residu asam amino yang berperan dalam interaksi molekular yang terbentuk selanjutnya diamati dengan menggunakan perangkat lunak BIOVIA Discovery Studio 2020.

\section{Hasil dan Diskusi}

Ekstrak butanol dari daun bidara arab (Ziziphus sphinachristi L.) yang telah diisolasi mengandung empat glikosida saponin triterpenoidal yang diberi nama christinin-A. Christinin-A merupakan senyawa saponin utama dengan struktur inti steroida yang selanjutnya diturunkan menjadi beberapa senyawa seperti christinin-B, C, dan D [7,8]. Daun bidara arab ini telah banyak digunakan sebagai cairan antiseptik alami dalam pencegahan infeksi pada permukaan kulit. Melalui penelitian ini akan diprediksikan lebih lanjut mengenai afinitas dan interaksi molekular yang terbentuk antara senyawa christinin-A, B, C, dan D terhadap reseptor target pada beberapa bakteri yang meliputi PenicillinBinding Protein 3 (PBP3) dari Escherichia coli [9], Filamentous Temperature-Sensitive Mutant Z (FtsZ) dari Staphylococcus epidermidis [10], dan N-myristoyl Transferase dari Candida albicans [11].

Optimasi geometri molekul senyawa uji dalam bentuk struktur tiga dimensi dilakukan dengan menggunakan perangkat lunak GaussView 5.0.8 dan Gaussian09.
Hasil optimasi geometri molekul senyawa uji dengan konformasi terbaik dipilih berdasarkan nilai energi total [25]. Berdasarkan hasil optimasi geometri molekul senyawa uji yang terdapat pada Tabel 1, senyawa christinin-A, B, C, dan D memiliki nilai energi total yang baik dan diprediksi akan mampu berinteraksi dengan baik pada bagian sisi aktif pengikatan makromolekul target. Energi total yang dihasilkan melalui perhitungan dalam perangkat lunak Gaussian09 digunakan untuk menggambarkan konformasi struktur molekul senyawa uji telah mendekati keadaan aslinya dan diharapkan mampu membentuk interaksi molekular yang stabil dengan makromolekul target.

Sebelum dilakukan simulasi penambatan molekular terhadap keempat senyawa christinin, terlebih dahulu harus dilakukan validasi metode untuk menentukan beberapa parameter yang akan digunakan pada simulasi penambatan molekular. Validasi metode terhadap parameter penambatan molekular dilakukan dengan menggunakan metode re-docking kemudian dilakukan pengamatan terhadap nilai Root Mean Square Deviation (RMSD). Hasil yang diperoleh dari tahapan validasi metode menunjukkan bahwa parameter yang akan digunakan dalam simulasi penambatan molekular telah memenuhi persyaratan karena memiliki nilai RMSD kurang dari 2 A (Tabel 2) [26,27].

Simulasi penambatan molekular dilakukan dengan menggunakan perangkat lunak MGLTools 1.5.6 yang dilengkapi dengan AutoDock 4.2 untuk mengamati

Tabel 3. Nilai energi bebas ikatan hasil simulasi penambatan molekular

\begin{tabular}{lccc}
\hline \multirow{2}{*}{ Senyawa Uji } & \multicolumn{3}{c}{ Energi Bebas Ikatan (kkal/mol) } \\
\cline { 2 - 4 } & Escherichia coli & Staphylococcus epidermidis & Candida albicans \\
\hline Amoksisilin & $-6,04$ & & \\
Tiamfenikol & & $-4,52$ & \\
Flukonazol & & & $-5,89$ \\
Christinin-A & $-7,85$ & $-6,02$ & $-8,35$ \\
Christinin-B & $-7,64$ & $-5,50$ & $-6,58$ \\
Christinin-C & $-6,84$ & $-6,80$ & $-7,71$ \\
Christinin-D & $-6,62$ & $-4,74$ & $-8,16$ \\
\hline
\end{tabular}




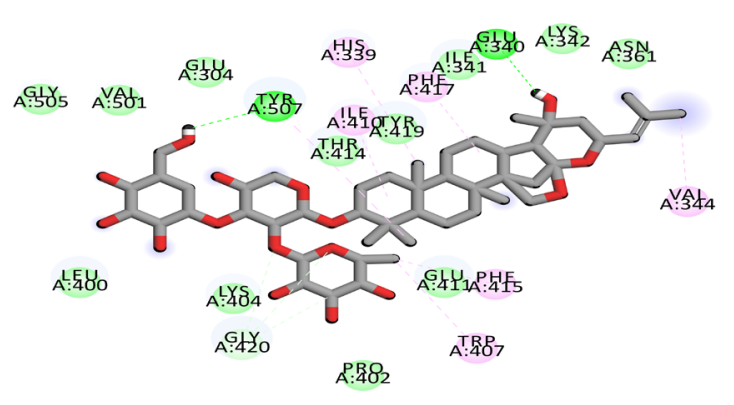

Christinin-A + Escherichia coli

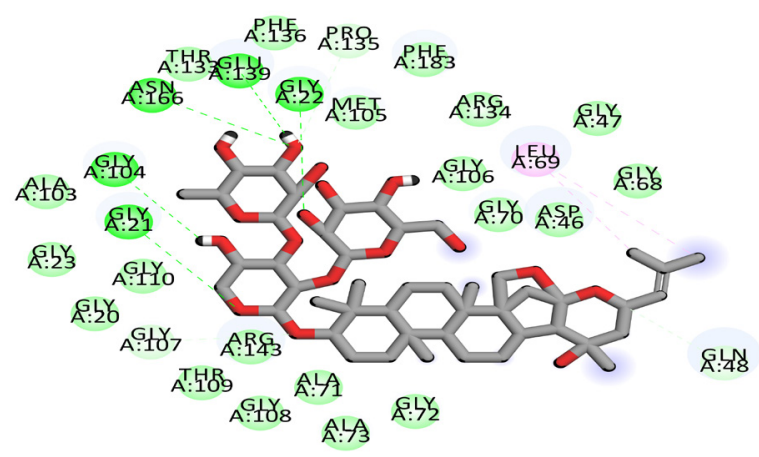

Christinin-C + Staphylococcus epidermidis

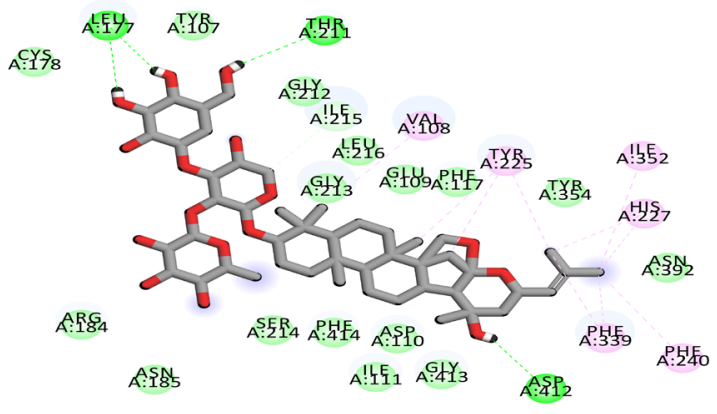

Christinin-A + Candida albicans

Gambar 3. Interaksi Molekular antara Makromolekul Target dan Senyawa Christinin

afinitas paling baik diantara keempat molekul senyawa uji, serta mengidentifikasi, mengevaluasi, dan mengeksplorasi interaksi molekular yang terbentuk terhadap makromolekul target. Pose pengikatan protein-ligan dengan konformasi terbaik hasil penambatan molekular dipilih dan dibandingkan berdasarkan nilai energi bebas ikatan $[23,24]$. Berdasarkan data hasil simulasi penambatan molekular yang terdapat pada Tabel 3, molekul senyawa christinin-A memiliki afinitas yang paling baik terhadap Penicillin-Binding Protein 3 (PBP3) dari Escherichia coli dan $\mathrm{N}$-myristoyl Transferase dari Candida albicans, yaitu dengan nilai energi bebas ikatan masing-masing sebesar $-7,85$ $\mathrm{kkal} / \mathrm{mol}$ dan $-8,35 \mathrm{kkal} / \mathrm{mol}$.

Fenomena yang berbeda ditunjukkan ketika molekul senyawa uji berinteraksi dengan Filamentous TemperatureSensitive Mutant Z (FtsZ) dari Staphylococcus epidermidis, dari hasil simulasi penambatan molekular senyawa christinin-C memiliki afinitas yang paling baik dengan nilai energi bebas ikatan sebesar -6,80 kkal/mol. Menariknya, apabila dibandingkan dengan beberapa antimikroba yang telah banyak digunakan di pasaran senyawa christinin memiliki afinitas yang lebih baik. Di samping itu, bagian pengikatan keempat senyawa christinin tidak jauh berbeda dengan ligan alami yang terdapat pada masing-masing makromolekul target [28]. Dengan demikian, dapat diprediksi bahwa senyawa christinin-A, B, C, dan D merupakan kandidat yang dapat dimanfaatkan sebagai komponen utama antiseptik alami.

Pengamatan lebih lanjut dilakukan terhadap interaksi molekular yang terbentuk dari kompleks molekul senyawa uji dan makromolekul target. Seperti yang ditunjukkan pada Gambar 3, dapat diamati bahwa interaksi molekular yang terbentuk antara kompleks senyawa christinin-A dan Penicillin-Binding Protein 3 (PBP3) dari Escherichia coli meliputi 5 ikatan hidrogen (dengan Glu340, Gly420, dan Tyr507) dan 7 interaksi hidrofobik (dengan His339, Val344, Trp407, Ile410, Phe415, Phe417, dan Tyr507). Kemudian kompleks senyawa christinin-A dan N-myristoyl Transferase dari Candida albicans mampu membentuk 14 interaksi molekular yang terdiri dari 5 ikatan hidrogen (dengan Leu177, Thr211, Ile215, dan Asp412) dan 9 interaksi hidrofobik (dengan Val108, Tyr225, His227, Phe240, dan Phe339).

Sementara kompleks senyawa christinin-C dan Filamentous Temperature-Sensitive Mutant Z (FtsZ) dari Staphylococcus epidermidis hanya mampu membentuk 10 
interaksi molekular diantaranya 8 ikatan hidrogen (dengan Gly21, Gly22, Gln48, Gly104, Gly107, Pro135, Glu139, dan Asn166) dan 2 interaksi hidrofobik (dengan Leu69). Berdasarkan identifikasi terhadap interaksi yang terbentuk, senyawa christinin sebagian besar mampu berikatan dengan bagian sisi aktif dari masing-masing makromolekul target. Fenomena tersebut menunjukkan bahwa afinitas yang kuat dan stabil dari senyawa tersebut karena banyaknya kontribusi dari ikatan hidrogen, interaksi elektrostatik, dan interaksi hidrofobik [29].

\section{Kesimpulan}

Molekul senyawa christinin yang berasal dari daun bidara arab (Ziziphus sphina-christi L.) telah terbukti mampu menghambat ketiga makromolekul target pada Escherichia coli, Staphylococcus epidermidis, dan Candida albicans melalui identifikasi, evaluasi, dan eksplorasi terhadap afinitas dan interaksi molekuler yang terbentuk dengan menggunakan simulasi penambatan molekular secara in silico. Berdasarkan hasil penelitian ini diperoleh bahwa senyawa christinin-A memiliki afinitas yang paling baik terhadap Penicillin-Binding Protein 3 (PBP3) dari Escherichia coli dan $\mathrm{N}$-myristoyl Transferase dari Candida albicans, dengan nilai energi bebas ikatan masing-masing $-7,85 \mathrm{kkal} / \mathrm{mol}$ dan $-8,35 \mathrm{kkal} / \mathrm{mol}$. Kemudian senyawa christinin-C memiliki afinitas yang paling baik terhadap Filamentous TemperatureSensitive Mutant Z (FtsZ) dari Staphylococcus epidermidis, dengan nilai energi bebas ikatan $-6,80 \mathrm{kkal} / \mathrm{mol}$. Dengan demikian, senyawa tersebut memiliki potensi sebagai kandidat komponen utama dalam formulasi antiseptik alami.

\section{Ucapan Terima Kasih}

Penulis mengucapkan terima kasih kepada Program Studi Farmasi dan Laboratorium Riset, Fakultas Matematika dan ilmu Pengetahuan Alam, Universitas Islam Bandung yang telah menyediakan semua fasilitas dalam melaksanakan penelitian ini.

\section{Referensi}

[1]. Jebur MH. The Activity of Aquatic Extract of Ziziphus Spina-christi against Bacteria, an in Vitro Study. Int J Psychosoc Rehabil. 2020; https://doi.org/10.37200/iipr/v24i5/pr201854

[2]. A.Al-Hajry M MEA, A A-M. Antibacterial Activity of Silver Nanoparticles Synthesized by Sidr (Ziziphus spina- Christi) Leaf Extract against Pathogenic Bacteria. Int J Curr Microbiol Appl Sci. 2016; https://doi.org/10.20546/ijcmas.2016.504.028
[3]. Abalaka ME, Daniyan SY, Mann A. Evaluation of the antimicrobial activities of two Ziziphus species (Ziziphus mauritiana L. and Ziziphus spinachristi L.) on some microbial pathogens. African J Pharm Pharmacol. 2010;

[4]. Adamu H, Abayeh O, Ibok N, Kafu S. Antifungal activity of extracts of some Cassia, Detarium and Ziziphus species against dermatophytes. Indian J Nat Prod Resour. 2006;

[5]. Pirbalouti AG, Jahanbazi P, Enteshari S, Malekpoor F, Hamedi B. Antimicrobial activity of some Iranian medicinal plants. Arch Biol Sci. 2010; https://doi.org/10.2298/ABS1003633G

[6]. Asgarpanah J. Phytochemistry and pharmacologic properties of Ziziphus spina christi (L.) Willd. African J Pharm Pharmacol. 2012; https://doi.org/10.5897/aipp12.509

[7]. Hussein Mahran GED, Glombitza KW, Mirhom YW, Hartmann R, Michel CG. Novel saponins from Zizyphus spina-christi growing in Egypt. Planta Med. 1996; https://doi.org/10.1055/s-2006-957842

[8]. Niamat R, Khan MA, Khan KY, Ahmed M, Mazari P, Ali B, et al. A review on zizyphus as antidiabetic. Journal of Applied Pharmaceutical Science. 2012.

[9]. Sauvage E, Derouaux A, Fraipont C, Joris M, Herman R, Rocaboy M, et al. Crystal structure of penicillin-binding protein 3 (PBP3) from Escherichia coli. PLoS One. 2014; https://doi.org/10.1371/journal. pone.0098042

[10]. Tripathy S, Sahu SK, Azam MA, Jupudi S. Computer-aided identification of lead compounds as Staphylococcal epidermidis FtsZ inhibitors using molecular docking, virtual screening, DFT analysis, and molecular dynamic simulation. J Mol Model. 2019; https://doi. org/10.1007/s00894-019-4238-6

[11]. Jays J, Mohan S, Saravanan J. MOLECULAR DOCKING STUDIES OF NOVEL FURAN-AZETIDINONE HYBRID COMPOUNDS AS POTENTIAL ANTIFUNGAL AGENTS. Int Res J Pharm. 2019; https://doi. org/10.7897/2230-8407.100260

[12]. Frisch MJ, Trucks GW, Schlegel HE, Scuseria GE, Robb MA, Cheeseman JR, et al. Gaussian 16. Gaussian, Inc., Wallingford CT,. 2016.

[13]. Solapure S, Dinesh N, Shandil R, Ramachandran V, Sharma S, Bhattacharjee $D$, et al. In vitro and in vivo efficacy of $\beta$-lactams against replicating and slowly growing/nonreplicating mycobacterium tuberculosis. Antimicrob Agents Chemother. 2013; https://doi. org/10.1128/AAC.00023-13

[14]. Fujita J, Maeda Y, Nagao C, Tsuchiya Y, Miyazaki Y, Hirose M, et al. Crystal structure of FtsA from Staphylococcus aureus. FEBS Lett. 2014; https://doi.org/10.1016/i.febslet.2014.04.008

[15]. Sogabe S, Masubuchi M, Sakata K, Fukami TA, Morikami K, Shiratori $\mathrm{Y}$, et al. Crystal structures of Candida albicans N-myristoyltransferase with two distinct inhibitors. Chem Biol. 2002; https://doi. org/10.1016/S1074-5521(02)00240-5

[16]. Egorova KS, Gordeev EG, Ananikov VP. Biological Activity of Ionic Liquids and Their Application in Pharmaceutics and Medicine. Chemical Reviews. 2017. https://doi.org/10.1021/acs. chemrev.6b00562

[17]. Kurniawan F, Miura Y, Kartasasmita RE, Mutalib A, Yoshioka N, Tjahjono DH. In silico study, synthesis, and cytotoxic activities of porphyrin derivatives. Pharmaceuticals. 2018; https://doi. org/10.3390/ph11010008

[18]. Hevener KE, Zhao W, Ball DM, Babaoglu K, Qi J, White SW, et al. Validation of molecular docking programs for virtual screening against dihydropteroate synthase. J Chem Inf Model. 2009; https:// doi.org/10.1021/ci800293n

[19]. Lans I, Anoz-Carbonell E, Palacio-Rodríguez K, Aínsa JA, Medina M, Cossio $P$. In silico discovery and biological validation of ligands of FAD synthase, a promising new antimicrobial target. PLOS Comput Biol. 2020; https://doi.org/10.1371/journal.pcbi.1007898

[20]. Bikadi Z, Hazai E. Application of the PM6 semi-empirical method to modeling proteins enhances docking accuracy of AutoDock. J Cheminform. 2009; https://doi.org/10.1186/1758-2946-1-15

[21]. Morris GM, Goodsell DS, Halliday RS, Huey R, Hart WE, Belew RK, et al. Automated docking using a Lamarckian genetic algorithm and an empirical binding free energyfunction.J ComputChem.1998; https:// doi.org/10.1002/(SICI)1096-987X(19981115)19:14<1639::AIDJCC10>3.0.CO;2-B 
[22]. Nasab R, Hassanzadeh F, Khodarahmi G, Rostami M, Mirzaei M, Jahanian-Najafabadi $A$, et al. Docking study, synthesis and antimicrobial evaluation of some novel 4-anilinoquinazoline derivatives. Res Pharm Sci. 2017; https://doi.org/10.4103/1735$\underline{5362.213988}$

[23]. Pantsar T, Poso A. Binding affinity via docking: Fact and fiction. Molecules. 2018. https://doi.org/10.3390/molecules23081899

[24]. Liu T, Lin $Y$, Wen $X$, Jorissen RN, Gilson MK. BindingDB: A webaccessible database of experimentally determined protein-ligand binding affinities. Nucleic Acids Res. 2007; https://doi.org/10.1093/ nar/gk1999

[25]. Mohammad RK, Madlol RA, Umran NM, Sharrad FI. Structure and electronic properties of substitutionally doped Cycloheptane molecule using DFT. Results Phys. 2016; https://doi.org/10.1016/j. rinp.2016.11.039
[26]. Pagadala NS, Syed K, Tuszynski J. Software for molecular docking a review. Biophysical Reviews. 2017. https://doi.org/10.1007/ s12551-016-0247-1

[27]. Yang Z, Rannala B. Molecular phylogenetics: Principles and practice. Nature Reviews Genetics. 2012. https://doi.org/10.1038/nrg3186

[28]. Veeraragavan V, Radhakrishnan N, Chidambaram R. Predicting the biodegradability nature of imidazole and its derivatives by modulating two histidine degradation enzymes (urocanase and formiminoglutamase) activities. Asian J Pharm Clin Res. 2017; https://doi.org/10.22159/ajpcr.2017.v10i11.20999

[29]. Fakih TM. Dermaseptin-Based Antiviral Peptides to Prevent COVID-19 through In Silico Molecular Docking Studies against SARSCoV-2 Spike Protein. Pharm Sci Res. 2020; https://doi.org/10.7454/ psr.v7i4.1079. Copyright $\odot 2020$ The author(s). You are free to share (copy and redistribute the material in any medium or format) and adapt (remix, transform, and build upon the changes were pad You may do so in any resonable mann but not in any way that suggets the licensor endores you or your use; ShareAlike - If you remix transform, or build upon the material, you must distribute your contributions under the same license as the original (https://creativecommons.org/licenses/by-sa/4.0/) 